\title{
STUDI KRITIS TERHADAP PERBANKAN SYARIAH DALAM PRAKTEK MUDHARABAH
}

\author{
Oleh: IBNU RUSYDI, SH., M.Pd.I.*)
}

\begin{abstract}
Islamic banking productsin the formof savings generally use mudharabah and there is also awadi'ah. It is published by Islamic bank son the productsand work processes Islamic bank, when examinedmore deeplyandca refully to match the application Islamic banking is currently the instrumentto its legislation and various provisionsof shariaeither already accommodated in the compilation of National Sharia Board fatwa (DSN) as well asthe provision containedin the books of jurisprudence muamalah the scholarsof the salaf, it found many similarities concept o fislamic bank swith that conventional bank makes can not bealigned premises sharia compliance and irregularities inperaktek islamic banking which were linked with the contractmudharabah.in ireggularities such irregularitiesof islamic banksin violation ofsharia could drag wellatusurious transactions.
\end{abstract}

\section{ABSTRAK}

Produk perbankan syariah dalam bentuk tabungan umumnya menggunakan akad mudharabah dan sebagiannya ada juga yang berakad wadi'ah. Hal yang dipublikasikan oleh bank syariah atas produk dan proses kerja bank syariah, biladicermati lebih mendalam dan seksama dengan mencocokan penerapan peraktek perbankan syariah saat ini dengan instrumen undang-undangnya maupun berbagai ketentuan syariah baik yang sudah diakomodir dalam kompilasi fatwa Dewan Syariah Nasional (DSN) maupun ketentuan yang terdapat dalam kitab kajian fikih muamalah para ulama salaf, ternyata ditemukan berbagai kesamaan konsep bank syariah dengan bank konvensional yang membuatnya memang tidak bisa selaras denga ketentuan syariah serta banyaknya penyimpangan dalam peraktek perbankan syariah diantaranya yang berhubungan dengan akad mudharabah.Dalam penyimpangan-penyimpangan tersebut bank syariah melakukan pelanggaran terhadap syariah yang bisa menyeretnya pula pada transaksi ribawi.

Kata kunci : Mudharabah, Perbankan Syari'ah.

\section{PENDAHULUAN}

Maraknya bank-bank syariah belakangan ini bisa menggambarkan adanya potensi pasar perbankan syariah di Indonesia.Hal ini seolah bisa menjadi indikator telah munculnya kesadaran sebagian umat Islam di Indonesia terhadap penerapan syariah Islam dalam kehidupan bermuamalah yang bebas dari riba dan meninggalkan aktivitas bisnis haram lainnya. Bankbank konvensional yang lebih dahulu hadir dianggap tidak mampu mengakomodir tuntutan perubahan sistem yang diharapkan umat Islam selain masih rentan menggunakan sistem ribawi, bank konvensional juga masih tidak memperdulikan pemutaran

\footnotetext{
*) Tenaga Pengajar Fakultas Hukum Universitas Galuh
} 
uang nasabah apakah untuk investasi dalam bisnis yang di halalkan atau di haramkan menurut ketentuan syariat Islam. Di saat umat Islam mulai menyadari dengan kebutuhan tersebut maka saat itulah mulai muncul perbankan syariah yang berupaya menyelaraskan peraktek perbankan dengan ajaran Islam serta meninggalkan berbagai aktivitas yang lazim dilakukan oleh bank-bank ribawi (bank konvensional) yang sarat dengan peraktek riba dan aktivitas investasi pada objek yang diharamkan agama.

Jika dilihat dari tujuan dan latar belakang kemunculan bank-bank syariah, tentu sangat pantaslah bank syariah menuai pujian dan dukungan sebagai institusi perbankan alternatif bagi umat Islam yang membutuhkan jasa perbankan tanpa dihantui dosa riba dan aktivitas terlarang lainnya, namun seiring waktu berjalan, saat terjadinya interaksi diantara praktisi perbankan, pengguna perbankan (nasabah) dengan para ahli ilmu (para ulama) serta kajiankajian yang mendalam maka sedikit demi sedikit mulai bermunculan temuan berbagai penyimpangan yang terjadi baik pada proses akad muamalah berlaku yang diterapkan oleh bank syariah maupun konsep dasarnya yang melandasi berdirinya perbankan syariah baik dalam produk pendanaan maupun produk pembiayaannya.

Konsentrasi pembahasan dalam tulisan ini adalah mengenai akad mudharabah yang di terapkan oleh bank syariah guna memberi gambaran dan penegasan mengenai kebenaran ada atau tidaknya penyimpangan peraktek akad mudharabah yang dilakukan oleh bank syariah, mengingat akad mudharabah merupakan akad muamalah paling utama yang melandasi produk perbankan syariah, sebab akad inilah yang mendasari berbagai transaksi perbankan syariah.

\section{PEMBAHASAN}

\subsection{Pengertian Riba dan Akad Mudharabah}

Penyebab utama umat Islam meninggalkan bermuamalah dengan bank konvensional serta beralih menuju kepada perbankan syariah (Islamic Banking) adalah dikarenakan alasan peraktek riba yang masih merajalela dan diterapkan oleh bank konvensional dalam sebagian besar transaksinya. Umat Islam mulai memahami bahwa konsep yang digunakan dalam pembagian bunga bank baik dalam konteks pendanaan maupun pembiayaan bank konvensional mengadopsi cara dan konsep riba. 
Peran ulama dan proses pembelajaran kepada pemahaman syariah yang benar, membuat umat Islam dapat mengetahui bahwa bunga bank merupakan implementasi dari transaksi riba. Oleh sebab itu, di sinilah perlunya pengetahuan mengenai hakikat dari suatu masalah agar tidak tertipu dari penamaan-penamaan lain yang kelihatannya baik namanya, namun sebenarnya tetap buruk hakikatnya.

Agar bisa menjauhi riba, maka diperlukan pengetahuan mengenai apa itu yang dimaksud dengan riba. Syafi'i Antonio (2003:37) mendefinisikan riba sebagai berikut "Riba secara bahasa bisa bermakna ziyadah atau tambahan. Dalam pengertian lain, secara linguistik, riba juga berarti tumbuh dan membesar. Adapun menurut istilah teknis, riba berarti pengambilan tambahan dari harta pokok atau modal secara batil. Ada beberapa penjelasan dalam menjelaskan riba, namun secara umum terdapat benang merah yang menegaskan bahwa riba adalah pengambilan tambahan, baik dalam transaksi jual beli maupun pinjam meminjam secara batil atau bertentangan dengan prinsip muamalah dalam Islam. Sementara itu Muhammad Arifin Badri (2009:2) mendefiniskan Riba sebagai suatu "akad/transaksi atas

barang tertentu yang ketika akad berlangsung, tidak diketahui kesamaannya menurut ukuran syariat atau dengan menunda penyerahan kedua barang yang menjadi obyek akad atau salah satunya".

Dari definisi tersebut diketahui jika riba bisa muncul pada jual beli, pinjam meminjam, hal tersebut bisa terjadi karena melanggar ketentuan yang dibenarkan syariat. Semisal contoh dari yang diatur syariat ialah tidak dibolehkannya mengambil keuntungan dari utang piutang, karena akad transaksi utang piutang dalam ketentuan prinsip muamalah Islam haruslah berakad sosial dan tidak boleh di komersilkan. "Setiap piutang yang mendatangkan kemanfaatan/ keuntungan, maka itu adalah riba." (baca al-Muhadzdzab karya al-Syairazi 1/304).

Hukum riba adalah haram menurut kesepakatan ulama Islam, dan riba masuk salah satu diantara dosa besar maka umat Islam dilarang mengambil riba apapun jenisnya, banyak sekali dalil baik dari al-Qur'an maupun al-Sunnah yang menyatakan haramnya dan terlarangnya riba. Muhammad bin Shalih al Utsaimin seperti dikutip oleh Muhammad Arifin badri (2009:19) mengatakan "Keharaman riba telah disepakati oleh 
ulama. Oleh karena itu, barangsiapa yang mengingkari keharamannya, sedangkan ia tinggal di masyarakat muslim, berarti ia telah murtad (keluar dari agama Islam), karena riba termasuk hal-hal haram yang telah jelas dan diketahui oleh setiap orang serta telah disepakati"

$$
\text { Sementara itu, akad }
$$

mudharabah menurut Ahmad alSyarbasyi sebagaimana dikutip Syafii Antonio (2003:95) adalah akad kerja sama usaha antara dua pihak dimana pihak pertama (shâhibu al-mâl) menyediakan seluruh (100\%) modal, sedangkan pihak lainnya sebagai pengelola. Keuntungan usaha secara mudharabah dibagi menurut kesepakatan yang dituangkan dalam kontrak, sedangkan apabila rugi ditanggung oleh pemilik modal selama kerugian itu bukan akibat kelalaian si pengelola. Sedangkan kerugian yang diakibatkan karena kecurangan atau kelalaian si pengelola, si pengelola harus bertanggung jawab atas kerugian tersebut. Menurut Sa'ad al-Silmi sebagaimana dikutip Arifin Badri(2010: 131) mudharabah adalah suatu akad dagang antara dua pihak, pihak pertama sebagai pemodal, sedangkan pihak kedua sebagai pelaksana usaha, dan keuntungan yang diperoleh dibagi antara mereka berdua dalam prosentase yang telah disepakati antara keduanya. Sedangkan rukun-rukun mudharabah itu sebagaimana disebutkan oleh wahbah zuhayli (1985: Juz 5: 3792) antara lain:

1. ljab dan qobul

ljab ialah perkataan yang diucapkan oleh pihak pertama yang menghendaki terjalinnya akad mudharabah, Sedangkan qobul merupakan jawaban yang mengandung persetujuan yang diucapkan pihak kedua atau yang mewakilinya. Tidak ada kata-kata khusus dalam hal ini sebagaimana amalan ibadah layaknya sholat, haji dan sebagainya namun mudharabah merupakan wujud interaksi sesama manusia, sehingga teknisnya yang menunjukan kesepakatan kedua belah pihak dapat diungkapkan apa saja sesuai kebiasaan yang berlaku baik bisa berupa lisan maupun tulisan

2. Pemodal dan pelaku usaha

Orang yang dibolehkan untuk menjalin akad mudharabah harus memenuhi empat kriteria yaitu orang yang merdeka, oleh sebab itu hamba sahaya tidak dibenarkan untuk bertransaksi tanpa seizin tuannya, telah baligh bagi laki-laki telah diketahui sampai mencapai umur lima belas tahun atau telah bermimpi junub sedang pada wanita ditandai 
dengan mulainya siklus datang bulan (haidh), atau hamil atau telah berumur lima belas tahun, berakal sehat, oleh sebab itu orang yang mengalami gangguan jiwa atau serupa tidak sah akad perniagaanya, dan kriteria terakhir ialah mampu membelanjakan hartanya dengan baik.

\section{Modal}

Modal ialah harta milik pihak pertama (pemodal) kepada pihak kedua (pelaku usaha) guna membiayai usaha yang dikerjakan oleh pihak kedua. Para ulama telah menyebutkan sejumlah persyaratan bagi harta yang menjadi modal akad mudharabah diantaranya:1) diketahui jumlah modalnya oleh kedua belah pihak supaya tidak menimbulkan perselisihan dalam pembagian keuntungan, hal ini karena konsekuensi akad mudharabah yang mengembalikan modal kepada pemodal lalu kedua belah pihak berbagi keuntungan; 2) penyerahan modal kepada pelaku usaha dan pelaku usaha tersebut sepenuhnya diberi kebebasan untuk menggunakan modal tersebut untuk membiayai usaha yang dilakukannya.

4. Usaha

\begin{tabular}{lcr}
\multicolumn{1}{c}{ Dalam } & menjalin & akad \\
mudharabah & umumnya & ulama \\
membagi atas & dua bagian yakni \\
Mudharabah & al-muthlaqah
\end{tabular}

(mudharabah bebas). Adalah sistem mudharabah, yang dalam hal ini, pemilik modal (shâhib al-Mal atau investor) menyerahkan modal kepada pengelola tanpa pembatasan jenis usaha, tempat dan waktu, ataupun dengan siapa pengelola bertransaksi. Jenis ini memberikan kebebasan kepada mudhârib (pengelola modal) untuk melakukan apa saja yang dipandang dapat mewujudkan kemaslahatan. Kemudian ada pula mudharabah al-muqayyadah (mudharabah terbatas). Dalam hal ini, pemilik modal (investor) menyerahkan modal kepada pengelola dan menentukan jenis usaha, tempat, waktu, ataupun pihakpihak yang dibolehkan bertransaksi dengan mudharib.

5. Keuntungan

Tujuan utama diadakannya akad mudharabah adalah memperoleh keuntungan kedua belah pihak, pemodal dananya berkembang dengan keuntungan dan pengusaha menikmati laba usaha (keuntungan) hasil operasi.

\subsection{Ketidaksesuaian}

Akad

Mudharabah Pada Bank Syariah dengan Akad Mudharabah Syar'i

$$
\text { Dengan }
$$

mengkaji,

membandingkan, meneliti serta melakukan tinjauan berdasar berbagai literatur fikih muamalah syaríah, 
peraturan perbankan syariah serta praktek dan aktualisasi yang terjadi berdasar literatur yang mengambil objek pada bank syari'ah maupun melakukan observasi kepada pihak-pihak yang terlibat dalam aktualisasi perbankan syariah maka terdapat ketidaksesuaian akad mudharabahbank syariah di Indonesia dengan akad mudharabah yang syar'i. Hal ini bisa di tinjau dari halhal sebagai berikut:

1. Status ganda perbankan syariah menyalahi ketentuan akad mudharabah sesuai syar'i menurut yang dipahami para ulama fikih Islam.

Dalam menjalankan akad mudharabah terhadap para nasabah pihak bank melakukan status ganda, pertama bank berlaku sebagai pengelola usaha (mudhârib) dan kemudian bank dalam waktu sekejap berubah status menjelma menjadi investor (shâhibual-mâl).

Berikut penjelasan skenario status ganda bank: bank syariah menghimpun dana dari nasabah pertama yang datang menabung dengan akad mudharabah, dalam hal ini bank memposisikan nasabah sebagai pemilik modal dan bank syariah sendiri mengklaim sebagai pelaku usahanya, ketika uang modal sudah dalam penguasaan bank, maka bank tidak menjalankan dengan amanah apa yang semestinya dilakukan oleh pihak pelaku usaha dalam akad mudharabah namun justru bank kembali mengikat diri lagi dengan perjanjian mudharabah kepada pihak lain yakni nasabah kedua.

Dalam konteks kedua ini bank mengklaim sebagai pemilik modal dan nasabah yang datang kali ini adalah pihak pelaku usaha sesungguhnya yang benar-benar membutuhkan curahan bantuan modal untuk usahanya. Menyimak skenario status ganda bank syariah tersebut maka diketahui dalam dua akad mudharabah yang dilakukan bank syariah tersebut baik akad mudharabah dengan nasabah pertama ketika bank memposisikan diri sebagi pelaku usaha maupun pada mudharabah dengan nasabah kedua ketika bank kemudian memposisikan diri sebagi pemilik modal, seandainya bank melakukan mudharabah dengan nasabah kedua atas izin pemilik modal (nasabah pertama) maka bank tidak berhak mendapat bagian keuntungan dan menentukan nisbah bagi hasil karena statusnya hanya sebagai calo perantara atau makelar dana saja. Para ulama menjelaskan bahwa hasil keuntungan dalam akad mudharabah 
hanya milik pemodal dan pelaku usaha, sedangkan pihak yang tidak memiliki modal dan tidak ikut serta dalam pelaksanaan usaha maka pihak bank tidak berhak untuk mendapatkan bagian dari hasil keuntungan (bagi hasil).

Para ulama melarang peraktek mudharabah yang dilakukan bank syariah saat ini sebagaimana yang dikemukakan oleh al-Nawawi yang di kutip dan dibenarkan dalam sejumlah kitab-kitab fikih klasik para ulama salaf: "Hukum kedua: tidak dibenarkan bagi pelaku usaha (mudharib) untuk menyalurkan modal yang ia terima kepada pihak ketiga dengan perjanjian mudharabah. Bila ia melakukan hal itu atas seizin pemodal, sehingga ia keluar dari akad mudharabah (pertama) dan berubah status menjadi perwakilan bagi pemodal pada akad mudharabah kedua ini, maka itu dibenarkan. Akan tetapi ia tidak dibenarkan untuk mensyaratkan dirinya sedikitpun dari keuntungan yang diperoleh. Bila ia tetap mensyaratkan hal itu, maka akad mudharabah kedua bathil" (alNawawi: 230)

2. Bank syariah hakikatnya menjalankan akad utang piutang dan bukan akad mudharabah dalam hubungannya dengan nasabah.
Jika dicermati lebih jauh pada status ganda perbankan maka akan didapati bahwa yang dilakukan oleh bank syariah sesungguhnya saat ini merupakan akad utang piutang dan bukan mudharabah,. Kamuflase pada bentuk akad dan istilah syar'i tidaklah merubah hakikat sebenarnya pada susbtansi akad utang piutang dalam skenario status ganda bank. Berikut skenario akad utang piutang yang dijalankan oleh bank syariah meskipun melabeli namanya dengan akad mudharabah.

Pihak bank yang dalam status pertama sebagai pelaku usaha dan menerima modal dari nasabah pertama (diasumsikan sebagai kreditur) kemudian tidak amanah untuk menjalankan perannya sebagai pelaku usaha sesuai akad mudharabah dimaksud, namun bank syariah malah kemudian menyalurkan kembali dana tersebut kepada pihak nasabah lain (diasumsikan sebagai debitur) yang hendak berlaku sebagai pelaku usaha, pada kali ini bank memposisikan diri sebagai pemodal yang pada hakikatnya uang modal yang ada pada bank merupakan uang milik nasabah pada akad mudharabah pertama. Jadi subtansi dari skenario status ganda perbankan ini ialah bank berupaya 
mengalokasikan dana terhimpun dari pihak lain yang dijanjikan akan kembali dananya oleh bank seiring waktu berjalan beserta bagi hasilnya (bunga uang). Hal ini berjalan dari suatu usaha kosong yang pada hakikatnya tidak pernah bank lakukan kecuali hanya menerima dan menyalurkan dana serta mengambil keuntungan atasnya (menyerupai pinjaman bank terhadap uang nasabah pada bank konvensional yang disertai bunga pinjaman).

Aliran uang nasabah pertama tadi kemudian di lokasikan oleh bank dalam bentuk penyaluran dana kepada pihak lainnya (bank syariah pada hakikatnya bukan pemilik uang yang sebenarnya), dimana bank kali ini menuntut pengembalian dana seiring waktu berjalan beserta bagi hasilnya (bunga uang) atas modal yang hakikatnya bukan milik bank namun milik nasabah pertama yang berperan sebagai kreditur, dengan catatan dalam kedua proses tadi diisyaratkan adanya keuntungan atasnya, sebagaimana telah diketahui bahwa pengambilan keuntungan dari utang piutang adalah riba.

3. Kegiatan usaha bank syariah yang masih memplagiasi aturan main kegiatan bank konvensional akan bermasalah dalam implementasi akad mudharabahnya.

Penjelasan Bank Indonesia dalam Ikhtisar Undang-Undang No. 21 Tahun 2008 Tentang Perbankan Syariah menyatakan bahwa "Bank Syariah yang terdiri dari BUS dan BPRS (Pasal 18) serta UUS, pada dasarnya melakukan kegiatan usaha yang sama dengan bank konvensional yaitu melakukan penghimpunan dan penyaluran dana masyarakat disamping penyediaan jasa keuangan lainnya."

Dari undang-undang tersebut dapat dipahami pada dasarnya setiap bank, baik itu yang masih konvensional maupun bank yang melabeli diri dengan label syari'ah adalah lembaga perantara (intermediary) antara sektor yang kelebihan dana (surplus) dan sektor yang kekurangan dana (minus). Bank menerima simpanan berupa giro, tabungan dan deposito dari pihak kelebihan dana. Dana yang terhimpun lalu disalurkan ke pihakpihak yang memerlukan dalam bentuk kredit/pinjaman/pembiayaan. Pihak yang kelebihan dana mendapatkan imbalan atas dana yang ditempatkan di bank yaitu berupa bunga/bagi hasil. 
Pada sisi lain, pihak yang minus atau memanfaatkan kredit/ pinjaman/pembiayaan dari bank harus membayar imbalan kepada bank berupa bunga/bagi hasil/margin. Biaya operasional dan laba bank diperoleh dari selisih imbalan yang diberikan oleh pihak yang memanfaatkan dana (debitur) dengan imbalan yang diberikan bank kepada nasabah deposan. Oleh karena itu,tampaklah bahwa fungsi bank syariah sama dengan bank konvensional. Bank syariah menghimpun dana dari masyarakat lalu disalurkan kepada pihak yang membutuhkan (fungsi intermediary), mekanisme fungsi intermediary yakni dengan menghimpundana nasabah dan menerapkan akad mudharabah dua pihak oleh bank baik pertama terhadap posisi nasabah sebagai investor kemudian melakukan penyaluran pada nasabah lain yang diposisikan sebagai pelaku usaha. Oleh sebab itu, pada hakikatnya bank hanya melakukan instrumen pendanaan utang piutang kemudian mengambil keuntungan atas transaksi tersebut sehingga jatuhlah pada riba. Dari sini semakin jelas, bahwa instrumen yang mengacu pada undang-undang perbankan syariah tidak bisa kompatibel dengan akad mudharabah yang sesuai dengan prinsip syari'ah.

4. Undang-undang Perbankan syariah tidak mengisyaratkan bank syariah untuk memiliki usaha real dan terjun langsung dalam dunia usaha, dengan hal ini bank syariah sulit untukdapat menjalankan akad mudharabah pada usaha riil yang hakikatnya memang tidak pernah dimiliki.

Hal ini didasarkanpada Undang-Undang Nomor 21 Tahun 2008 tentang Perbankan Syariah Pasal 4 ayat 1 dan 2 yang menyebutkan:

(1) Bank Syariah dan UUS wajib menjalankan fungsi menghimpundan menyalurkan dana masyarakat.

(2) Bank Syariah dan UUS dapat menjalankan fungsi sosial dalam bentuk lembaga baitul mal, yaitu menerima dana yang berasal dari zakat, infak, sedekah, hibah, atau dana sosial lainnya dan menyalurkannya kepada organisasi pengelola zakat.

Begitu pun dalam Pasal 19 Undang-Undang Nomor 21 Tahun 2008 tentang Perbankan Syariah Pada ayat 1 tentang kegiatan usaha Bank Umum Syariah dan ayat 2 tentang kegiatan usaha UUS

Bank syariah berfungsi untuk a) menghimpun dana dalam bentuk Simpanan berupa Giro, Tabungan, atau bentuk lainnya yang dipersamakan dengan itu berdasarkan Akad wadi'ah atau Akad 
lain yang tidak bertentangan dengan Prinsip Syariah; b) menghimpun dana dalam bentuk Investasi berupa Deposito, Tabungan, atau bentuk lainnya yang dipersamakan dengan itu berdasarkan Akad mudharabah atau Akad lain yang tidak bertentangan dengan Prinsip Syariah; c) menyalurkan Pembiayaan bagi hasil berdasarkan Akad mudharabah, Akad musyarakah, atau Akad lain yang tidak bertentangan dengan Prinsip Syariah; d) menyalurkan Pembiayaan berdasarkan Akad murabahah, Akad salam, Akad istishna', atau Akad lain yang tidak bertentangan dengan Prinsip Syariah;

Dari pasal di atas menjadi jelas bahwa semua jenis produk perbankan syari'ah hanya sebatas pembiayaan dan pendanaan. Dengan demikian, pada setiap unit usaha yang dikelola, peran perbankan hanya sebagai penyalur dana nasabah dan ini menyebabkan sulit untuk mendapatkan perbedaan antara perbankan syari'ah dan perbankan konvensional, hal ini dikarenakanbank syariah tidak mempunyai usaha riil, selain hanya memudharabahkan kembali dana nasabah, dengan kemungkinan lain yakni dana nasabah pertama disalurkan dalam bisnis pembiayaan bank.

Sebagai pihak yang beritikad baik dan berinvestasi dalam usaha yang dikelola bank syariah maka perlu pula untuk mengetahui apakah bisnis yang dijalankan oleh bank benar dan sesuai syar'i. Dalam menjalankan produk usaha pembiayaan (bai'al-murabahah) bank syariah memposisikan diri sebagai penjual barang (skenario ini agar terpenuhinya akad syar'i, bank harus membeli dahulu barang yang akan dijual kepada konsumen) untuk sejumlah barang-barang konsumtif yang dibutuhkan seperti kendaraaan bermotor, rumah dan lainnya sesuai Dewan Syariah Nasional (yang selanjutnya disingkat DSN) pada fatwanya No: 04/DSN-MUI/IV/200, tentang Murabahah menyatakan: "Bank membeli barang yang diperlukan nasabah atas nama bank sendiri, dan pembelian ini harus sah dan bebas riba."

Namun adakah bank syariah yang benar-benar mempraktekan ini, dalam praktek sistem murabahah yang dilakukan bank syariah tidak sesuai dengan fatwa DSN, hal ini seperti contoh kasus proses pembiayaan murabahah di Bank BRI Syariah Ciamis dimana nasabah diharuskan membayar uang muka (urbun) sebesar $20 \%$ dari nilai kredit yang diajukan kepada pihak developer terlebih dahulu untuk mengambil KPR dengan angsuran 10 tahun, dengan margin keuntungan 
sebesar 9,5\% (margin biasa ditentukan terlebih dahulu oleh bank sesuai lamanya waktu angsuran).

Dari kasus ini terdapat kritikan untuk bank yakni bank memberikan piutang, hal ini terbukti bahwa nasabah membayarkan urbun ke developer dan bukan kepada bank dan hal ini tidak tepat dikatakan hubungan jual beli antara bank dengan konsumen, jika pun diasumsikan bahwa bank melakukan aktivitas penjualan maka bank menjual sesuatu yang sepenuhnya belum diserah terimakan kepadanya dan ini menyalahi al-Sunnah sebagaimana hadis riwayat Abu Daud yang artinya sebagai berikut: dari Hakim bin Hizam, "ia berkata kepada Rasulullah: wahai Rasulullah, ada orang yang mendatangiku. Orang tersebut ingin mengadakan transaksi jual belidenganku terhadap barang yang belum aku miliki, bolehkah aku membelikan barang tertentu yang dia inginkan di pasar setelah bertransaksi dengan orang tersebut?kemudian Rasulullah bersabda: Janganlah kau menjual barang yang belum kau miliki."' (HR. Abu Daud, no. 3505; dinilai sahih oleh al-Albani)

Dari hadis di atas menunjukkan beberapa hal 1) terlarangnya menjual barang yang belum selesai diserahterimakan; 2) larangan menjual barang yang belum selesai diserahterimakan ini berlaku bagi bahan makanan dan barang lainnya; 3) barang yang sudah dibeli harus berpindah tempat terlebih dahulu sebelum dijual kembali kepada pihak lain.

Secara garis besarnya praktek akad pembiayaan murabahah baik untuk pembiayaan renovasi rumah, pembelian kendaraan bermotor, pembelian rumah KPR, pengadaan modal kerja maupun pengadaan barang lain pada umumnya berjalan dengan skema bank (ba ial-Murabahah) membelikan terlebih dahulu barang tersebut dari supplier kemudian penjual (ba'i) menjual barang tersebut pada konsumen (musytari) melalui akad murabahah dengan harga sebesar harga pokok ditambah keuntungan yang telah disepakati antara ba'i dan musytari.

5. Bank tidak siap menanggung kerugian

Akad mudharabah adalah akad yang oleh para ulama telah disepakati akan kehalalannya. Karena itu, akad ini dianggap sebagai tulang punggung praktek perbankan syariah. DSN-MUI telah menerbitkan 
fatwa no: 07/DSN-MUI/IV/2000, yang kemudian menjadi pedoman bagi praktek perbankan syariahakan tetapi praktek bank syariah perlu ditinjau ulang. Pada fatwa dengan nomor tersebut, DSN menyatakan: "LKS (lembaga Keuangan Syariah) sebagai penyedia dana, menanggung semua kerugian akibat dari mudharabah kecuali jika mudharib (nasabah) melakukan kesalahan yang disengaja, lalai, atau menyalahi perjanjian."

Praktek perbankan syariah di lapangan masih jauh dari apa yang difatwakan oleh DSN. Andai perbankan syariah benar-benar menerapkan ketentuan ini, niscaya masyarakat akan berbondongbondong mengajukan pembiayaan dengan skema mudharabah, namun kembali lagi, fakta tidak sejalan dengan teori. Perbankan syariah yang ada belum sungguh-sungguh menerapkan fatwa DSN secara utuh. Sehingga pelaku usaha yang mendapatkan pembiayaan modal dari perbankan syariah, masih diwajibkan mengembalikan modal secara utuh, walaupun ia mengalami kerugian usaha.

Para ulama dari berbagai mazhab telah menegaskan bahwa pemilik modal tidak dibenarkan untuk mensyaratkan agar pelaku usaha memberikan jaminan seluruh atau sebagian modalnya. Sehingga apa yang diterapkan pada perbankan syariah, yaitu mewajibkan atas pelaku usaha untuk mengembalikan seluruh modal dengan utuh bila terjadi kerugian usaha adalah persyaratan yang batil bahkan dalam ilmu fikih bila suatu akad terdapat persyaratan yang batil, maka akad persyaratan tersebut tidak sah sehingga masing-masing harus mengembalikan seluruh hakhak lawan akadnya atau akad tetap dilanjutkan dengan meninggalkan persyaratan tersebut.

6. Semua nasabah mendapatkan bagi hasil

Bank syariah mencampur adukan seluruh dana yang masuk kepadanya tanpa dipilah mana yang sudah disalurkan ke usaha bank maupun yang masih beku dan belum tersalurkan, namun demikian pada setiap akhir bulan seluruh nasabah mendapatkan bagian dari hasil/keuntungan. Hal ini didasarkan bahwa pertimbangan bank dalam membagi keuntungan adalah total modal bukan keuntungan yang diperoleh dari dana masing-masing nasabah. Pembagian keuntungan tersebut menjadi masalah besar dalam metode mudharabah yang 
memegang prinsip islami. Pembagian hasil kepada nasabah yang dananya belum tersalurkan jelaslah akan merugikan nasabah yang dananya telah tersalurkan.

7. Metode bagi hasil yang berbelit-belit Muhammad Arifin Badri (2010: 173-175) mengungkapkan metode bagi hasil yang diterapkan oleh salah satu perbankan syari'ah di Indonesia :

Bagi hasil nasabah= $\frac{\text { dana/saldo nasabah } \times \mathrm{E} \times \text { Rasio/nisbah nasabah }}{1000}$

$E=$ Pendapatan rata-rata investasi dari setiap 1000 rupiah dari nasabah

Sementara, metode perhitungan hasil mudharabah yang benar-benar syar'i dengan rumus hitung yakni: Bagi hasil nasabah=keuntungan bersih $\mathrm{x}$ nisbah nasabah $\mathrm{x}$ nisbah modal nasabah dari total uang yang dikelola oleh bank

Perbedaan antara dua metode tersebut bisa diketahui dari contoh kasus berikut. Pak ahmad menginventasikan modal sebesar $\mathrm{Rp}$ 100.000.000, dengan perjanjian 50\% untuk pemodal dan $50 \%$ untuk pelaku usaha (bank), dan total uang yang dikelola oleh bank berjumlah $\mathrm{Rp}$ 10.000.000.000 (10 miliar). Dengan demikian, modal Pak Ahmad adalah $1 \%$ dari keseluruhan dana yang dikelola bank. Pada akhir bulan bank berhasil membukukan laba bersih sebesar Rp 1.000.000.000 (1 miliar). Operator bank setelah melalui perhitungan yang berbelit belit menentukan bahwa pendapatan investasi dari setiap Rp 1000 adalah Rp 11,61. Bila menggunakan metode perbankan syariah maka hasilnya:

$\frac{100.000 .000 \times 11,61 \times 50=R p .580 .500}{1000} 100$

Pak Ahmad hanya mendapat Rp 580.500, sedangkan jika menggunakan metode mudharabah dengan prinsip islami yang sebenarnya maka hasilnya sebagai berikut :

$\frac{100.000 .000 \times 50 \times 1=\text { Rp. } 5.000 .000}{1000} 100$

Dengan metode perhitungan mudharabah yang benar Pak Ahmad mendapatkan bagi hasil yang lebih menguntungkan.

\section{KESIMPULAN}

Berdasarkan data, tinjauan dan pembahasan yang telah dilakukan, maka dapat ditarik beberapa kesimpulan sebagai berikut :

1. Undang-undang perbankan syariah masih memplagiasi kepada aturan perundangundangan perbankan konvensional. 
2. Status ganda bank dengan mudharabah dua pihak dalam mengakomodir peraturan undang-undang perbankan syariah yang saat ini diterapkan tidak sesuai dengan fikih mudharabah yang dikenal para ulama.

3. Bank syariah tidak siap menanggung kerugian, sebab merupakan sesuatu yang musykil dalam menjalankan usaha tidak mendapatkan kerugian.

4. Selama perbankan syariah tidak terjun langsung dalam dunia usaha dan hanya mencukupkan diri sebagai penyalur dana nasabah maka tidak akan pernah terhindar dari riba.

5. Semua nasabah pasti mendapat bagi hasil, jaminan uang nasabah tidak akan mengalami kerugian dan perhitungan bagi hasil yang berbelit-belit tidak sesuai akad mudharabah murni yang diajarkan islam.

\section{DAFTAR PUSTAKA}

Al-Nawawi, al-Minhaj, Lebanon, Dar alFikri.

Antonio, Syafi'i Muhammad, 2001, Bank Syariah dari Teori ke Praktik, Jakarta, Gema Insani Press.
Badri, Arifin Muhammad, 2010, Riba dan Tinjauan Kritis Perbankan Syari'ah, Bogor, Pustaka Darul IImi. , 2010, Tinjauan Kritis Perbankan Syariah, Jakarta, Makalah Seminar Nasional KPMI.

Bank Indonesia, 2008, Ikhtisar Undang Undang No. 21 Tahun 2008 Tentang Perbankan Syariah. Jakarta.

Daud, AbuSunan Abu Daud, Lebanon, Dar al-Fikri.

DSN MUI, 2000, Fatwa DSN MUI No. 07/DSN-MUI/IV/2000 Tentang Pembiyaan Mudharabah (Qiradh), Jakarta.

Zuhaily Wahbah, 1985, al-Fiqh al-Islamy wa adillatuhu, Lebanon, Dar Fikr. 